\title{
PUNCTURING THE IN-BETWEEN: BODY PIERCING IN POSTMODERNITY
}

\author{
Elena Arguedas González \\ Carolina Chan Villalta
}

\begin{abstract}
RESUMEN
Este artículo explora la problemática de la perforación corporal. Usando las teorías de los estudios culturales, la perforación es leída como un texto que manifiesta el carácter de las relaciones sociales. Se puede considerar la perforación como una subcultura que se rebela en contra de ciertos lineamientos de los grupos hegemónicos. Sin embargo, también se le puede ver como un elemento más dentro de la cultura "pop", ya que ha sido asimilada e incorporada por los mismos grupos hegemónicos que trató de cuestionar. Por lo tanto, el tema de las políticas del cuerpo está íntimamente ligado a la práctica de la perforación corporal. Como todo acto, la perforación se subdivide y repliega, dejándole espacio para la subversión.

Palabras clave: estudios culturales, postmodernismo, cuerpo, perforaciones, modificación corporal, poder.
\end{abstract}

\begin{abstract}
This article delves into the problematic of piercing. In the line of cultural studies, piercing is read as a text that sheds light on societal relationships. Body piercing can be seen as a subculture, rebelling against certain stands of hegemonic groups, but it can also be viewed as another element of "pop" culture, having been assimilated and incorporated by the same hegemonic groups it attempted to question. Therefore, linked to body piercing is the matter of the politics of the body. Like all practices, piercing subdivides and folds, thus allowing it room for revolt.
\end{abstract}

Key words: cultural studies, postmodernism, the body, piercing, body modification, power.

"It is only shallow people who do not judge by appearances. The true mystery of the world is the visible, not the invisible."

- Oscar Wilde, The Picture of Dorian Gray

Carolina Chan Villalta. Bachiller en inglés. Profesora en la Universidad de Costa Rica, estudiante de la Maestría en Literatura Inglesa.

Elena Arguedas González. Bachiller en inglés. Estudiante de la Maestría en Literatura Inglesa, Universidad de Costa Rica.

Recepción: 2-5-05

Aceptación: 23-8-05 
We
wash it,
shampoo it,
brush it,
clean it,
feed it,
starve it,
shave it,
paint it,
cover it,
adorn it.

But is it really ours?

Is it signifier or signified?

perfume it, Do we rule our body?

A process, a product, a stage, a symbol, a
bridge, a statement?

What does it mean when we alter our bodies?

\begin{abstract}
What are we saying with
our bodies?

What is our body saying about us? What do people

read from my body?

Is my body an extension of the dominant, Catholic, patriarchal, capitalist, homogenizing ideology that pervades in the country?
\end{abstract}

Is it possible to step out of this machinery?

If I decide to pierce my body, what will happen?

Who will I aggravate? To whom belongs the final smirk?

\title{
Am I a puppet?
}

Am I in control(led)?

Foucault already spoke of the long history clinging to the body. The body has been theorized abundantly and still much has been ignored. How can one really talk about the body? Yet it is not the body in the abstract that interests us but specific instances, and, concretely, the phenomenon of body piercing. Our initial hypothesis is (was) that body piercing has become a mass product, sucked in and spit out by a capitalist hegemonic group that endeavors in "massifying" everyone and controlling rebellion. Nonetheless, our investigation has distanced us from interpreting and "reading" and has driven us towards pleasure, as well as apathy in regards to meaning. With piercing, we were driven into a Susan Sontagian universe: against interpretation. Even though piercing has been assimilated and made corporate, there are centrifugal undercurrents that run through it, making piercing a truly postmodern product ${ }^{1}$. As a cultural practice, it is a pastiche of many things, fragment 
after fragment of individual experiences that somehow get turned into a general mass. Even though in many ways piercing is passé since it has been left aside in favor of branding, scarring, and bodily suspension, it nevertheless stirs up a feeling of unrest and makes a large number of people cringe. As we experience piercing as ambling bodies and become (as Foucault would say) theory ourselves, the more we get sucked into the web of clockwise and counterclockwise movements within these world(s).

In James Myers' definition of "body modification," piercing, as well as cosmetics, coiffure, tattooing, scarification, cutting, and branding, among many others, are carried out for mostly "aesthetic reasons" (1992: 267). Likewise, Greif and Hewitt explain that piercing refers to "the insertion of a needle into various areas of the body to create an opening through which decorative ornaments such as jewelry may be worn" (1999: 368 emphasis added). Nonetheless, viewing piercing or any other related practice in this manner is too simplistic. Whether it be for aesthetic, decorative, religious, mystic, or sexual reasons, it is nor really clear why people pierce their bodies. We will not pause long on this issue, since it is obtuse to make generalizations or to pigeonhole humanity. Be it the tongue, nipples, nostril, navel, lips, labia, eyebrow, ear cartilage, ear lobe, ear tragus, perineum, penis, scrotum, septum, or clitoris, piercing is one of culture's most noteworthy borderlands: in the margins between authority and subversion.

\section{The Navel, The Nose, The Ears...}

"Culture is capitalism's way of getting people to construe domination as freedom."

-Rivkin

Los precios de los "twinkles" varían según el modelo: los sencillos (sin brillantes) cuestan entre $\phi 15.000$ y $\phi 20.000$, y los de brillantes, entre $ф 20.000$ y $\phi 25.000$.

— "Piercing ¿en los dientes?"

Body piercing, as most everything, generates capital. Such an opportunity could not be passed over by the capitalist, hegemonic group that predominates in Costa Rica. Luis Britto argues in El imperio contracultural: del rock a la posmodernidad that "Toda operación productiva es una campaña cultural. En los compradores deben ser promovidas necesidades y actitudes, valores y prioridades..." (1991: 27). Therefore, it is no mere coincidence that piercing has become a commodity that "responds," for instance, to specific needs that young people begin to "acquire" at a certain age. Independence, autonomy, self-sufficiency, "rebellion," rites of passage: these are advertised as the results of piercing one's body. Once you get pierced, you will finally be "different" and no longer a meat product worthy of Pink Floyd. "That is the magic of ideology: to make us do things that may be against our interests and to do them as if they were entirely self-willed" (1998: 238), as Rivkin states. The transition between high school and "the rest of your life" requires some initiation. Because, as Britto stresses, "parafraseando a Marx, podríamos decir que en la sociedad de consumo, no es el ser el que determina el consumo sino el consumo el que determina al ser" (1991: 29). Therefore, body piercing is utilized by the hegemonic group to sell, camouflaging this under the pretext of promoting difference and change.

By appropriating the symbolism of the once countercultural piercing community and spitting it forth as modes of rebellion and masquerading it as such, the hegemonic group once 
again dominates the centrifugal forces within society and, additionally, benefits from this. Britto asserts that

\begin{abstract}
Como este conflicto se refiere a la asunción de roles, no puede ser resuelto por el consumo de objetos que presten una utilidad funcional directa, sino mediante símbolos que tiendan puentes abstractos entre realidad y rol. El joven dotado de capacidad creativa inventa estos símbolos; aquel que no la tiene, los consume. El joven obsesionado por la integración consume los que lo acercan al rol que se espera de él; el distanciado usa aquéllos que lo diferencian. En todo caso, se trata de un mercado de símbolos: de un mercado cultural (1991: 53).
\end{abstract}

In "La moda del tatuaje llega a los despachos," the massification ${ }^{2}$ of the business of body modification is revealed:

\footnotetext{
...los negocios de tatuajes han sido durante los últimos años, curiosamente, uno de las actividades económicas que más ha crecido en los últimos años, solo por detrás de los relacionados con Internet, informática y telefonía móvil. Además, el hecho de que personas adineradas como cantantes de rock, modelos y deportistas acudan con regularidad a los salones de tatuajes ha provocado el nacimiento de un nuevo negocio de alto nivel, con buenas condiciones sanitarias, técnicas innovadoras y diseños rompedores (2003).
}

For instance, Coki Jara, of Plexus, states that piercing has gone up more than eighty percent in the last ten years. Rubén Agüiero, of Arte Primitivo, speaks of a fifty percent increment in the last three years. And, as Carlos Wo Ching affirms, "Ya ahora es más normal ver una persona con varias perforaciones en la calle. Ahora ver una persona con una sola perforación en la calle es demasiado normal. Igual ver varia gente que tenga un montón antes, por ejemplo, no era muy común, menos aquí en este país." La Nación, for example, publishes an article that reads:

\footnotetext{
Considerado hasta hace una década un adorno corporal de escaso gusto, el tatuaje se ha extendido en los últimos años de manera vertiginosa, hasta alcanzar ámbitos desconocidos, como las finanzas y la alta dirección de empresas. A ello ha contribuido el uso que han hecho de esta moda los ídolos sociales, como cantantes, actores y deportistas, así como la irrupción de jóvenes profesionales en todos los ámbitos económicos, incluidos los que hasta ahora se consideraban más conservadores. ("La moda del tatuaje llega a los despachos" 2003)
}

Even though talking about tattoos, it sketches a picture of how body modification has become "mainstream." In A Todo Dar, aside from the "typical" earring in the lobe, the models display plenty of rings in their navels, ears, and noses. As Foucault enounces, "Nothing is more material, physical, corporal than the exercise of power ("Docile Bodies"). Still, only certain types of piercings are fashionable. Jara, Agüero, and Wo Ching all coincide that it is trendy to adorn the following places: eyebrow, nose, ear, navel, and tongue. La Nación even advertises:

\footnotetext{
A la par del vestuario están los accesorios. Los más originales están hechos de madera, semillas o cáscara de coco y van desde collares, hasta cadenas en los pies ¡ojalá en los dos! Pero el mejor complemento entre las jóvenes es un piercing (un arete) en el ombligo, que de nuevo hace imperdonable un vientre con grasa. La mayoría lleva ese accesorio en ese agujerito, con diferentes tamaños aunque suficiente como para captar las miradas (Cantero 2003).
}

Thus, some piercings are used to continue objectifying ("para captar las miradas") and imposing ("hace imperdonable un vientre con grasa"). Which is why some people decide to pierce other parts of their bodies or resort to branding, scarification, implants, and play or industrial piercing. Consequently, capitalist hegemony even sets off class struggle within piercing. Again in La Nación, a marked differentiation is made between one's class and the piercing to wear: 
Pero esta vez el mito se ha roto y los ticos no siguieron la moda europea. 'Posiblemente porque en Costa Rica usar metales en los dientes tiene una connotación peyorativa. Se asocia con la clase social más modesta, y quienes pueden gastar en este tipo de adornos, no quieren identificarse con ella', comenta Gil (Echeverría 2003).

In fact, the same article emphasizes that it is better to purchase a "twinkle" than a piercing, since twinkles are placed on the teeth as if they were braces, making them "safe" and "nontoxic." Consequently, the hegemonic group swallows up the piercing subculture and regurgitates it as a product within hegemony itself. In a Foucauldian style, the body emerges as a useful force "only if it is both a productive body and a subjected body" (Foucault 1984: 173). But this subjection need not be violent nor direct: "it may be subtle, make use neither of weapons nor of terror and yet remain of a physical order" (Foucault 1984: 173). Britto explains that the same system controls and steers the culture of the dissident subgroup in order to make it manageable and profitable. Thus,

\footnotetext{
Lejos de ser afirmación de la diferencia y factor de oposición a lo establecido, termina por consistir en un conjunto de satisfacciones sustitutivas, mediante las cuales el marginado suaviza su desacuerdo con la cultura oficial y, en última instancia, halla posible su funcionamiento dentro de ella. La subcultura de la disidencia es transformada en subcultura de consumo. A tal fin, la producción industrial de la economía de mercado realiza un proceso de interferencia cultural y de falsificación de la conciencia, que se traduce en manipulación social (1991: 24).
}

In the same vein, Foucault talks about the "political economy" of truth, which cannot be separated from the network of consumerism, production, and political and economic interests. By sucking in and expulsing body piercing as a sardonic postscript, the hegemonic group is able to play down the unrest within society, while at the same time promoting consumerism, class differences, and a certain fashion.

As a result, the taboo that had been placed on piercing is partially removed when hegemony realizes that it can be lucrative and commercial. After all, a person who gets pierced does not halt the machinery of production. In "La moda del tatuaje llega a los despachos,"(2003) this is shown in a notorious way:

Así por ejemplo, según una encuesta publicada por The Wall Street Journal, la compañía automovilística Ford y la aeronáutica Boeing permiten a todos sus empleados, desde los ejecutivos seniors hacia abajo, llevar tatuajes y piercing, siempre que no sean operarios y el adorno no suponga un peligro para su trabajo.

Indeed, body piercing can be viewed as a form of controlled rebellion against the system, yet it is offered by the system itself with a bow. As Foucault declares in "Verdad y poder,"

\footnotetext{
Este tipo de discurso es, de hecho, un formidable instrumento de control y de poder. Se sirve, como siempre, de lo que dice, lo que siente, de lo que espera la gente. Explota su tentación de creer que basta para ser felices franquear el umbral del discurso y levantar alguna que otra prohibición. Y acaba recortando y domesticando los movimientos de revuelta y liberación. (1980: 151)
}

In Gramsci's eyes, the dominant group allows the youth to "represent" their subcultures in a theater that hegemony itself has built (Vázquez Sempértegui 2001: 82). When deliberately asked if piercing is a form of controlled rebellion that the system exerts, Coki Jara unperturbedly answers “yes.” Is piercing rebellious? Jara, Agüero, and Wo Ching concur that it is not. All of them maintain that there are other ways to express dissent. Thus, it is evidenced that the hegemonic group engulfs a sub-counterculture like piercing and takes away its rebelliousness, because, as Britto enounces: 


\begin{abstract}
Si los cultores de esta última [la contracultura] son numerosos, la sociedad no puede resolver la diferencia aislándolos o liquidándolos físicamente en masa, porque el costo político y económico de tales medidas sería prohibitivo, y porque las mismas podrían obligar al grupo disidente a revelarse abiertamente en defensa de su supervivencia. Debe, pues, sostener una ofensiva ideológica, un tipo especial de ofensiva destinada a devorar a sus propios hijos, a negar su propia capacidad de transformarse. (16)
\end{abstract}

Consequently, the dominant group interferes in subcultures in order to annul them and, in that manner, removes and globalizes their unity as an identity. Another mechanism, as Britto enlists, is “. .. la invención integral de subculturas 'de consumo', inocuas y falsificadas, que desorientan a los grupos marginados" (1991: 33). As La Nación corroborates, piercing is linked to enhancing the dominant ideal of "beauty." Expanding this idea, Holtham states that "in this context an upsurge in hitherto 'primitive' body modification practices among modern people can be aligned with the dominant discourses and pre-occupations of mainstream society in physical health and fitness" (2003). Therefore, hegemony has done to piercing what Britto describes in El imperio contracultural: del rock a la posmodernidad: it has appropriated, adopted, commercialized, and mass-produced its symbols, thus universalizing the symbol and inverting its meanings. As Foucault points out in Verdad y poder. Un diálogo sobre el poder y otras conversaciones:

\footnotetext{
Lo que hace que el poder se sostenga, que sea aceptado, es sencillamente que no pesa sólo como potencia que dice no, sino que cala de hecho, produce cosas, induce placer, forma saber, produce discursos; hay que considerarlo como una red productiva que pasa a través de todo el cuerpo social en lugar de como una instancia negativa que tiene como función reprimir. (1980: 137)
}

One of the reasons for this is the incorporation of body piercing into "cleanliness" and "specialization." The greatest attacks against piercing were thrown by doctors, the "spokesmen" of order, truth, and "normality." Emitting judgments that piercing could even kill (see "Bocas perforadas" in La Nación), piercing counterattacked by resorting to and promoting sterilization and hygiene. Rubin narrates that the "tattoo renaissance" in the West, for instance, "was bought about by the professionalization of the practice [...] helping to lessen the stigma on tattooing, thus broadening its appeal" (1988: 233). The business card of Dermagrafica, also, makes a point of specifying that it is an "Estudio clínico artístico profesional de tatuaje y body piercing" (emphasis added). Likewise, Coki Jara, Rubén Agüero, and Carlos Wo Ching emphasize the sanitary aspects of body piercing. They also give much importance to experience and the taking of precautions when piercing. Such measures manifest how body piercing acquiesces to the norms of the hegemonic group.

Hence, body piercing becomes "pop." According to Britto, "El pop... no fue otra cosa que la masiva apropiación de una simbología de desviantes por una cultura de aparato: la conversión de una contracultura en subcultura de consumo" (1991: 36). Pop is characterized for devouring symbols belonging to subcultures or countercultures and re-selling them (Britto 1991: 58). And pop re-sells in a global, massified way:

\footnotetext{
Añadamos que en el pop se ha querido ver, no una cultura, sino la cultura, la prefiguración ideológica de la unidad global, el creo universal capaz de trascender las culturas locales, 'aldeanas', y de convertir la tierra en una 'aldea global'. [...] Pop cabalístico, cuya unidad de símbolos triunfaría sobre la diversidad de contenidos, logrando así la absoluta independencia del fondo y de la forma, de la estructura y de la superestructura..." (Britto 1991: 68)
} 
Therefore, body piercing works as an extension of capitalism at times due to its assimilation, massification, and appropriation by the dominant group. It can become "normalized" and it can be made "pop," thus turning into a lucrative business of control and oppression.

\section{Pocketing, The Septum, The Nosebridge...}

\footnotetext{
"It was a world where the images constructed as barriers between one's self and the world were briefly let go, before they were made again. It was a moment of creativity, a moment of change"

-Bell Hooks "Straightening our Hair"
}

The cannons: mass communication; the cannonballs: ideologies. This is the war of the political, economic, and social hegemonic apparatuses on culture's body, as Britto affirms. In this struggle, body piercing stands out neither as a subculture nor as counterculture ${ }^{3}$. Not exactly the hegemonic group, piercing works within it. Thus, the piercers and the pierced are not marginal nor central, they are integrated and disintegrated, included and repelled by centrifugal and centripetal forces. Body piercing's divergence from the hegemonic stump is evidenced when even a mainstream newspaper, like La Nación, treats piercing as an "adorno agresivo" (Echeverría 2003) and a journalist can declare in Semanario Universidad that "...la víctima incita al acoso por su cuerpo y gracia juvenil: "Nótese que lo acusa alguien que no tiene reparo en mostrar públicamente el arete en su ombligo...' afirma Petronio Marcenaro", (González Suárez 2002: 16). Or, as a manifesto reads in a piercing site on the Internet: "Body Modification is a declaration of independence from the modern western world and their terribly anglican views on life." Body piercing is on the borders between almost acquiescing and overtly rebelling. At times it bends one way, at times another. As Gloria Anzaldúa explains, "Borders are set up to define the places that are safe and unsafe. [. . . A A border is a dividing line, a narrow strip along a steep edge. [...] It is in a constant state of transition. The prohibited and forbidden are its inhabitants. Los Atravesados live there [...] those who cross over, pass over, or go through the confines of the "normal"' (1987: 3). As Trinh seconds, existing in the borderline means that one is neither outside nor inside but "incurring constantly the risk of falling off one side or the other side of the limit while undoing, redoing, modifying this limit" (1991: 218). Therefore, although piercing can be viewed as fashionable, pop, and a decoy of the hegemonic group, it also pushes outward into subversion.

In a Derridean way, body piercing as a concept destabilizes endings and beginnings, boundaries and divisions, self and other, public and private, subject and object, and the outside and the inside 4 . Another example of this emerges in the relationship of piercing with religion. According to many priests, body piercing goes against what is dogmatized in The Bible. For instance, the first Goth Festival that was to be held in Costa Rica in the Sanatorio Durán in Tierra Blanca in August of 2003 was cancelled by the parson Hugo Bonilla. Vinicio Chacón, in "Ataque al Rock Gótico," gives an account of what took place: “El sacerdote dijo en misa que se iba a celebrar una actividad satánica, que constaba de ritos del siglo XVII.' [...] Al parecer las imágenes difundidas en un canal televisivo para promocionar el evento, en las cuales se mostraban ejemplos del espectáculo de perforaciones que se realizaría, fueron el motivo de la actitud del sacerdote" (2003: 8). According to some, The Bible does not approve of piercing. In order to justify this, 1 Corinthians 6:19 is quoted, where it is stated that "Do you not know that 
your body is a temple of the Holy Spirit, who is in you, whom you have received from God? You are not your own; you were bought at a price. Therefore honor God with your body." Since the body is supposedly sacred it must remain untouched and "pure." As is said in Deuteronomy 14:1, "You are the children of the Lord your God. Do not cut yourselves or shave the front of your heads...". Furthermore, Exodus 32:2 preaches: "Aaron answered them, "Take off the gold earrings that your wives, your sons and your daughters are wearing, and bring them to me." So all the people took off their earrings and brought them to Aaron." Rings or metallic spheres are foreign to the body, therefore, they work as symbols of impurity and profanity. It is noteworthy to pinpoint, however, that piercers and people with piercings are, in their majority, Catholics. In our survey, out of the forty percent who are pierced, twenty declare themselves Catholic. Moreover, Coki Jara, is against the traditional interpretation of The Bible:

\footnotetext{
Si fuera así, no se podrían cortar la barba, ni cortar el pelo, ni las mujeres se pondrían aretes, ni las mujeres se deberían de maquillar, es como ambiguo. Para mí La Biblia es como muy-se puede interpretar de tantas maneras. Pero para mí La Biblia es más metáfora que otra cosa. No es textual, no hay que tomarla textualmente, y hay que entender el porqué de cada cosa y la época y todo...
}

All the same, he is proud of belonging to the Catholic religion: "Católico a mí manera, pero sí, soy Católico. Creo en un Dios y creo en Jesucristo y en todo.” Rubén Agüero seconds this, too: "Creo en Dios." Thus, body piercing can also be seen as an extension of the adoration of Jesus Christ: one can achieve ecstasy through pain, like Jesus when he is crucified. Jara's views that pain leads to pleasure and spirituality is intimately linked to this philosophy. As a matter of fact, suffering, as a way of life, is taught by many religions as the means of arriving to a higher state of being. For that reason, piercing transits the borders because it can be both heretical and dominant, as a perpetuator of hegemonic, patriarchal beliefs.

Linked to this is Jara's assertion that a relationship exists between piercing and S\&M: "Y el fetichismo. A mí me encanta el fetichismo. Y también va muy relacionado. Es una sensación. Es un poco como de adrenalina y miedo y satisfacción-medio orgásmico..." The trespassing committed by piercing regarding pleasure is developed by Foucault in "Sex, Power, and the Politics of Identity:"

\footnotetext{
...[S\&M] is the recreation of new possibilities of pleasure, which people had no idea about previously. [...] I think it's a kind of creation, a creative enterprise, which has as one of its main features what I call the desexualization of pleasure. The idea that bodily pleasure should always come from sexual pleasure as the root of all our possible pleasure-I think that's something quite wrong. These practices are insisting that we can produce pleasure with very odd things, very strange parts of our body, in very unusual situations, and so on. (1997: 165)
}

This eroticization of the body through other activities places piercing on the border of subversion in regards to sexuality and pleasure. Piercing, consequently, can be seen as an act of creation, such as bell hooks talks about in "Straightening Our Hair." Thus, while at times encouraging dominant ideology, piercing can, at the same time, transgress. Like everything postmodern, body piercing contradicts itself and

suffers from a certain semantic instability: that is, no clear consensus about its meaning exists among scholars. [...] Indeterminacy often follows from fragmentation. The postmodernist only disconnects; fragments are all he pretends to trust. His ultimate opprobrium is 'totalization'-any synthesis whatever, social, epistemic, even poetic. Hence his preference for montage, collage, the found or cut-up literary object, for paratactic overhypotactic forms, metonymy over metaphor, schizophrenia over paranoia. (Hassan 1987: 87, 168) 
In one of its fragments, body modification counters the hegemonic discourse on the body. For instance, even though piercing may be viewed as an accomplice of a capitalist, individualist mindset, as Britto manifests:

\begin{abstract}
Las contraculturas...hablan siempre sobre un ser humano concreto, definido por una particularidad: joven, mujer, negro, chicano, puertorriqueño, aborigen, homosexual, alienado. Y no lo hacen para invitarlo a disolverse en una humanidad abstracta e impersonal, sino para exhortarlo a manifestar esa diferencia: a enfatizarla hasta lo agresivo. [...] De allí la polifonía, y hasta la contradicción de mensajes. (1991: 44)
\end{abstract}

This polyphony surfaces in declarations made by the piercers themselves. For example, Rubén Agüero, piercer of Arte Primitivo, can state that he believes piercing is part of a counterculture while then later on affirming that it does not constitute a form of rebellion. "Depende, es cuestión del individuo" (Wo Ching) summarizes the orchestra of voices that characterizes body piercing. Or, as Coki Jara states, "Yo en realidad no tengo que expresarle nada a nadie [...] Así soy yo, y mí me gusta, y al que le guste que me vuelva a ver y el que no, que vuelva la cara." Britto clarifies:

\begin{abstract}
El mensaje contracultural puede estar inusitadamente centrado en sí mismo, puesto que no tiene por objeto transmitir (informaciones u órdenes), sino, como la poesía, despertar connivencias a través de sutiles connotaciones: tocar puntos clave que revelen universos de vivencias ya compartidas, ya sabidas por emisor y receptor. De allí la aparente falta de estructuración formal y lógica; su relativo hermetismo para los no iniciados. (1991: 45)
\end{abstract}

In body piercing studios, though not explicit, one can feel an air of dissent. After all, subversion in a world that promotes uniformity and standardization deals with standing out. Jameson, in fact, has already noticed that "[El posmodernismo] significa también el fin del estilo considerado como único y personal, el fin de la pincelada individual distintiva (simbolizado por la progresiva primacía de la producción mecánica)" (1991: 39). Holtham draws a substantial difference between piercing in the West and other places: "What seems evident is that in traditional societies, ritual body modification practices connect people and their bodies to the reproduction of long established social positions whereas in the industrialised West body piercing seems to serve the function of individuating the self from society" (2003). Similarly, Paine believes that piercing allows the individual to "attempt to forge a genuine mode of selfexploration which does not rely on the current authenticating narratives of fashion" (1994: 14). As Susan Sontag exhorts, one is driven to feel with the body, to sense it and be aware of your corporeality. Interpretation and rationality are thrust aside in favor of sensuality and emotions. In addition, Britto expounds that

\footnotetext{
El destinatario o receptor del mensaje contracultural, en fin, no es llamado ni a la reverencia (como en el mensaje teocrático) ni a la separación (como en el nihilista) ni al sometimiento a la racionalidad abstracta, como en el mensaje moderno. Es convocado a la solidaridad: pero a una solidaridad ante todo consigo mismo, con su peculiaridad y subjetividad humanas. De allí el tono individualista y anarquizante de gran parte de la contracultura: 'Haz lo tuyo.' (1991: 46)
}

This attitude is expressed blatantly by the piercers: "Hay gente que lo ve por estética, otros que lo ven por moda y otros que siguen lo que es lo cultural" (Wo Ching). Or, as Coki Jara states: 
...es nada más una manera de encontrar su forma de ser. Hay cosas que son de uno, otras cosas que no [...] Hay gente que le gusta por el significado, otra gente no. Hay unos que se lo ponen por los guerreros. Cada cabeza es un mundo. A como viene gente con ideas muy locas vienen otros con ideas tan absurdas, como me lo hago porque mi mejor amiga me dijo que me lo hiciera.

The results of our survey are also significant: out of fifty people interviewed, thirtyseven answered that piercings constitute a way of calling attention to yourself, as well as a form of distinguishing yourself and being different. Furthermore, thirty-three wrote that piercings were rebellious and nine expressed that people with piercings were defiant. Multiplicity of voices, S\&M, detachment, the individual, and eroticization: by these means, body piercing expresses its dissent and talks back.

Another relevant trait of piercing is its direct relationship with the body. Hugo Assman affirms that "Todas las cosas materiales ejecutan una danza cultural e ideológica" (Bussing 1999: 8). As a material reality and construction, the human body needs to be analyzed as a canvas-text imbedded within specific times, cultures, economies, and ideologies, among others (we will not delve into the "psychological" dictums regarding the attention or inattention given to the body.) According to Shilling, the affluent West has developed the tendency to view the body as a malleable entity that is "unfinished" and perennially "becoming" (1993: 181). As Michel Foucault already noticed, the body has been historicized by a plethoric amount of people. Nonetheless, historians and others place their attention on the body as a biological unit. But Foucault argues that the body is directly immersed in the political field:

\footnotetext{
...las relaciones de poder operan sobre él una presa inmediata; lo cercan, lo marcan, lo doman, lo someten a suplicio, lo esfuerzan a unos trabajos, lo obligan a unas ceremonias, exigen de él unos signos. Este cerco político del cuerpo va unido de acuerdo con unas relaciones complejas y recíprocas, a la utilización económica del cuerpo; el cuerpo, en una buena parte, está imbuido de relaciones de poder y de dominación, como fuerza de producción; pero en cambio su constitución como fuerza de trabajo solo es posible si se haya prendido en un sistema de sujeción (en el que la necesidad es también un instrumento político cuidadosamente dispuesto, calculado y utilizado). (1980: 32-3)
}

Gymnastics, exercises, muscle-building, nudism, and the "glorification of the body beautiful" serve as tools of power, because, after all, the hegemonic group needs healthy bodies, as Foucault sustains. This triggers "the responding claims and affirmations, those of one's own body against power, of health against the economic system, of pleasure against the moral norms of sexuality, marriage, decency" ("Body/Power"). Thus, Foucault manifests, what once made power strong is used to attack it: "Power, after investing itself in the body, finds itself exposed to a counter-attack in that same body" ("Body/Power"). Consequently, perforations are a way to re-appropriate the body, to show discontent with Western hegemony's ideals of beauty: smoothness, absence of scars and markings, equilibrium, and "naturalness." As "object and target of power" (Foucault 1984: 180), the body that is pierced can be regarded as no longer "docile, subjected, used, transformed, and improved" (1984: 180). Foucault explores the subjection of the body in "Docile Bodies," arriving to the conclusion that

The human body was entering a machinery of power that explores it, breaks it down, and rearranges it. A 'political anatomy,' which was also a 'mechanics of power,' was being born; it defined how one may have a hold over others' bodies, not only so that they may do what one wishes, but so that they may operate as one wishes, with the techniques, the speed, and the efficiency that one determines. Thus discipline produces subjected and practiced bodies, 'docile' bodies. Discipline increases the forces of the body (in economic terms of utility) and 
diminishes these same forces (in political terms of obedience.) In short, it dissociates power from the body; in the hand, it turns it into an 'aptitude,' a 'capacity,' which it seeks to increase...” (1984: 182)

Even though pierced bodies do not detain or stop the production of goods nor hamper the process of increasing capital, they do put a halt, at least momentarily, to the control that the hegemonic group exerts over the body. Regaining the body could be a step towards exercising one's voice. Instead of viewing piercing as a fashion statement, it is a political manifesto which turns one's physical presence into a defiant response. Notwithstanding, centripetal forces can masterfully reverse the wheel at any moment.

Rivkin writes in Literary Theory: An Anthology that

\begin{abstract}
There is one strand of Marxism that sees literature and culture as merely expressing the values, ideals, and imperatives of capitalism. From this perspective, culture is simply a softer means of managing people than physical force or threats of starvation. But what cultural history teaches in fact is that culture is one of the few sites where one can pause, stand back, and look at the system critically. (1998: 233)
\end{abstract}

Body piercing belongs to such a site, it stands shakily in the border between rebelling, accepting, and acquiescing. Piercing may be seen as a branch of the hegemonic group or as a space of dissent and re-appropriation. As Coki Jara holds, we live within a capitalist world, there is no escape nor way out. The least we can do is take control over our bodies, distinguish ourselves in some manner, and feel as much pleasure (or pain) as we can. Whether marketed products or autonomous beings, the pierced continue to raise questions about our materiality and power.

\title{
Notes
}

1. Hassan, in "Toward a Concept of Postmodernism," (un)defines postmodernism: "[...postmodernism] remains uncertain, though we know that Federico de Onís used the word postmodernismo in his Antología de la poesía española e hispanoamericana (1882-1932), published in Madrid in 1934 [...] Pop and silence, or mass culture and deconstruction, or Superman and Godot-or as I shall later argue, immanence and indeterminacy-may all be aspects of the postmodern universe" (1987: 85-6).

2. Britto writes in El imperio contracultural: del rock a la posmodernidad: "Hay cultura 'de masa' cuando los aparatos ideológicos dominan al creador y conforman la obra de éste, a fin de manipular la conducta de grandes conjuntos de la población. Llamarla 'de masa' es tramposo. Se trata de una cultura 'de aparato', donde la masa es meramente receptora" (1991: 34).

3. We will employ Luis Britto's distinction between subcultures and countercultures. As the theorist states, a subculture diverges from the hegemonic group, but does not contradict it openly: "Cuando una subcultura llega a un grado de conflicto inconciliable con la cultura dominante, se produce una contracultura: una batalla entre modelos, una guerra entre concepciones del mundo, que no es más que la expresión de la discordia entre grupo que ya no se encuentran integrados ni protegidos dentro del conjunto del cuerpo social" (1991: 18). The thin line between subcultures and countercultures is accentuated also in the following statement: "La subcultura presenta rasgos contraculturales en el momento en que el grupo excluido libra una batalla por establecer su identidad y crear vínculos simbólicos connotadotes de la misma. Ello explica el énfasis en la producción de símbolos que caracteriza a las contraculturas. Explica también que el sistema pueda neutralizarlas apoderándose de ellos, universalizándolos, e invirtiendo su significado" (Britto 1991: 10).

4. It feels necessary at this point to clarify that we do not wish to perpetuate a dichotomous vision of the world. If anything, piercing smudges polarization. 


\section{Bibliography}

Agüero, Rubén. 25 Nov. 2003. Personal Interview.

Anzaldúa, Gloria. 1987. Borderlands/La Frontera: The New Mestiza. San Francisco: Spinsters/ Aunt Lute.

Britto, Luis. 1991. El imperio contracultural: del rock a la posmodernidad. Venezuela: Nueva Sociedad.

Bussing, Ilse. 1999. Cuando las paredes hablan: El graffiti de San Lucas. Tesis de Maestría, Universidad de Costa Rica.

Cantero, Marcela. 2003. "Calurosa pasarela." La Nación. 15 Jan. <http://www.nacion.com/ viva/2003/enero/15/portada.html>.

Chacón, Vinicio. 2003. “Ataque al Rock Gótico.” Semanario Universidad, 7 Aug.

Echeverría, Paula. 2003. "Piercing ¿en los dientes?” La Nación. 15 Jun. <http://www.nacion. com/dominical/2003/junio/15/dominical11.html>.

Foucault, Michel. Body/Power. <http://thefoucauldian.co.uk/bodypower.htm>.

1984. "Docile Bodies." The Foucault Reader. Ed. Paul Rabinow. Pantheon Books: New York.

1997. "Sex, Power, and the Politics of Identity." Ethics: Subjectivity and Truth. Ed. Paul Rabinow. Vol. 1. New York: The New Press.

1984. "The Body of the Condemned." The Foucault Reader. Ed. Paul Rabinow. Pantheon Books: New York.

1980. "Verdad y poder: Diálogo con M. Fontana." Un diálogo sobre el poder y otras conversaciones. Madrid: Alianza Editorial.

González Suárez, Mirta. 2002 . "Otro argumento en contra del acoso sexual.” Semanario Universidad, 23 Aug.

Greif, J., and W. Hewitt. 1999. “Tattooing and body piercing.” Clinical Nursing Research.

Hassan, Ihab. 1987. "Toward a Concept of Postmodernism.” The Postmodern Turn: Essays in Postmodern Theory and Culture. Ohio: Ohio State University Press.

Henderson, Mae G. 1995. "Introduction: Borders, Boundaries, and Frame(work)s." Borders, Boundaries, and Frames: Cultural Criticism and Cultural Studes. New York: Routledge. 
Holtham, Susan. 2003. "Body Piercing in the West: A Sociological Inquiry." 1 Nov. <http:// www.bmezine.com/pierce/bme-pirc.html>.

Holy Bible. 1978. U.S.A.: National Publishing Company.

Hooks, Bell. 1996. "Straightening Our Hair.” Identities: Readings from Contemporary Culture. Boston: Houghton Mifflin Company.

Jameson, Fredric. 1991. El posmodernismo o la lógica cultural del capitalismo avanzado. Barcelona: Ediciones Paidós Ibérica, S.A.

Jara, Coki. 2003. Personal Interview,17 Nov..

"La moda del tatuaje llega a los despachos." 2003. La Nación. 31 Aug. <http://www.nacion. com/ln_ee/2003/agosto/31/ultima/mu15.html>.

Myers, James. "Nonmainstream Body Modification: Genital Piercing, Branding, Burning, and Cutting." 1992. Journal of Contemporary Ethnography 21.

Ponchner, Debbie. 2003. "Bocas perforadas.” La Nación. 12 July <http://www.nacion.com/ viva/2003/julio/12/portada.html>.

Rivkin, Julie, and Michael Ryan. 1998. "Introduction: 'Starting With Zero: Basic Marxism." Literary Theory: An Anthology. Ed. Julie Rivkin and Michael Ryan. Oxford: Blackwell Publishers.

Rubin, A. 1988. Marks of Civilisation: Artistic Transformations of the Body. Los Angeles: Museum of Cultural History.

Shilling, Chris. 1993. The Body and Social Theory. London: Sage Press.

Sontag, Susan. 1973. "Against Interpretation.” Issues in Contemporary Literary Criticism. Ed. Gregory T. Polleta. Boston: Little Brown.

Trinh, Minh-ha T. 1991. Framer Framed. New York: Routledge.

Vázquez Sempértegui, Lola. 2001. “Culturas juveniles.” Acerca de jóvenes contraculturas y sociedad adultocéntrica. San José: Editorial Departamento Ecuménico de Investigaciones (DEI).

Wo Ching, Carlos. 2003. Personal Interview. 27 Nov. 